\title{
PENINGKATAN KEMAMPUAN PEMECAHAN MASALAH MATEMATIKA SISWA KELAS IV SD 3 TENGGELES MELALUI MODEL PEMBELAJARAN BERBASIS MASALAH MATERI PECAHAN
}

\author{
Novia Lika Nor Jannah, Eka Zuliana \\ Email: vhi.vhiea@gmail.com, zulianaeka@yahoo.co.id \\ Universitas Muria Kudus
}

\begin{abstract}
Mathematic learning process given orally to express the formula or mathematic concepts that used to do the problems. This learning process happened at SD 3 Tenggeles Mejobo Kudus. This condition caused students rarely improve mathematic problem solving ability. Based this problem writer conducted the research by using problem based learning model. The purpose of this research is determine the increase problem solving ability by applying problem based learning model in fraction material at SD 3 Tenggeles 2013/2014 academic year.

This research is classroom action research consists of two cycle they are: 1) planning, 2) acting, 3) observing and 4) reflecting. Data collection techniques such as interview, observation, test and documentation. The research instrument are: the form of interview, observation guideline, and test. The data obtained in this research were analyzed quantitatively and qualitatively.

Problem solving ability at the first cycle obtained the average value of 63,17 with a percentage of $65,22 \%$ completeness increased in the second cycle that received an average rating of 75.13 to $86.96 \%$ presentage completeness. Learning activities of students in problem solving through problem based learning model at the first cycle obtained the average value of 2,56 with good qualification. Increased in the second cycle that received an average score of 3,02 with a good qualification. The skill of teacher in managing learning of mathematic by applying problem based learning model has increased in the first cycle to the second cycle: 2.82 with a good qualification in the first cycle increased to 3.11 with a good qualification in the second cycle.

The conclusions of this research is the application of problem based learning model in fractions material can improve students' mathematics problem solving, learning activities of students in problem solving, as well as the skills of teachers in the learning of mathematics.

Writer suggest that the implementation of learning mathematics in elementary school should involve students actively to solve the problem. Teachers can apply problem based learning model to improve students' problem solving abilities.
\end{abstract}

Keyword: mathematic problem solving ability, problem based learning, fraction

\begin{abstract}
ABSTRAK
Pembelajaran matematika disampaikan dengan cara ceramah untuk menyajikan rumus atau konsep matematika yang akan digunakan untuk mengerjakan soal. Pelaksanaan pembelajaran tersebut terjadi di SD 3 Tenggeles Mejobo Kudus. Pelaksanaan pembelajaran matematika di SD 3 Tenggeles menyebabkan siswa jarang melatih kemampuan pemecahan masalah yang dimilikinya. Berdasarkan permasalahan tersebut peneliti melakukan penelitian dengan menggunakan model pembelajaran berbasis masalah. Tujuan dari penelitian ini yaitu untuk mengetahui peningkatan kemampuan pemecahan masalah dengan menerapkan model pembelajaran berbasis masalah pada materi pecahan di SD 3 Tenggeles tahun ajaran 2013/2014.
\end{abstract}


Penelitian ini merupakan penelitian tindakan kelas yang terdiri atas dua siklus. Masing-masing siklus terdiri atas, (1) perencanaan tindakan, (2) perlakuan dan pengamatan tindakan, dan (3) refleksi terhadap tindakan. Teknik pengumpulan data berupa wawancara, observasi, tes, dan dokumentasi. Instrumen penelitian berupa pedoman wawancara, pedoman observasi, dan tes. Data yang diperoleh pada penelitian ini, dianalisis secara kuantitatif dan kualitatif.

Kemampuan pemecahan masalah siklus I memperoleh nilai rata-rata 63,17 dengan persentase ketuntasan $65,22 \%$ mengalami peningkatan pada siklus II yang memperoleh nilai rata-rata 75,13 dengan presentate ketuntasan $86,96 \%$. Aktivitas belajar siswa dalam pemecahan masalah melalui model pembelajaran berbasis masalah siklus I memperoleh skor rata-rata 2,56 dengan kualifikasi baik, meningkat pada siklus II yang memperoleh skor rata-rata 3,02 dengan kualifikasi baik. Keterampilan pengelolaan guru dalam pembelajaran matematika dengan menerapkan model pembelajaran berbasis masalah mengalami peningkatan pada siklus I ke siklus II, yaitu skor rata-rata 2,82 dengan kualifikasi baik pada siklus I meningkat menjadi 3,11 dengan kualifikasi baik pada siklus II.

Simpulan pada penelitian ini yaitu penerapan model pembelajaran berbasis masalah pada materi pecahan dapat meningkatkan kemampuan pemecahan masalah matematika siswa, aktivitas belajar siswa dalam pemecahan masalah, serta keterampilan guru dalam pembelajaran matematika.

Peneliti menyarankan agar pelaksanaan pembelajaran matematika di SD harus melibatkan siswa secara aktif untuk memecahkan masalah. Guru dapat menerapkan model pembelajaran berbasis masalah untuk meningkatkan kemampuan pemecahan masalah siswa.

Kata kunci: kemampuan pemecahan masalah, pembelajaran berbasis masalah, pecahan

\section{PENDAHULUAN}

Trianto (2011:1) menyatakan pendidikan yaitu salah satu bentuk perwujudan kebudayaan manusia yang dinamis dan sarat perkembangan. Pendidikan yang mampu mendukung pembangunan di masa mendatang yaitu pendidikan yang mampu mengembangkan potensi yang dimiliki siswa, sehingga ia mampu menghadapi dan memecahkan masalah kehidupan. Menurut Buchori (dalam Trianto 2011:5), pendidikan yang baik yaitu pendidikan yang tidak hanya mempersiapkan para siswanya untuk sesuatu profesi atau jabatan, tetapi untuk menyelesaikan masalah-masalah yang dihadapinya dalam kehidupan sehari-hari.

Mata pelajaran Matematika perlu diberikan kepada semua siswa mulai dari sekolah dasar untuk membekali siswa dengan kemampuan berpikir logis, analitis, sistematis, kritis, dan kreatif, serta kemampuan bekerjasama. Pembelajaran matematika hendaknya dimulai dengan pengenalan masalah yang sesuai dengan situasi (contextual problem). Untuk meningkatkan kemampuan memecahkan masalah perlu dikembangkan keterampilan memahami masalah, membuat model matematika, menyelesaikan masalah, dan menafsirkan solusinya (BSNP, 2006:147).

Salah satu materi matematika yang sulit dipelajari siswa yaitu materi pecahan, khususnya materi menyelesaikan masalah yang berkaitan dengan pecahan. Berdasarkan wawancara dengan guru kelas IV, materi pecahan dianggap sulit oleh siswa karena, (1) siswa kurang memiliki kemampuan prasyarat (memahami materi KPK) untuk mempelajari pecahan, (2) siswa sulit memahami konsep dari pecahan, (3) siswa belum memahami bentuk-bentuk pecahan, (4) siswa kurang mampu menyelesaikan operasi pecahan berpenyebut berbeda. Pembelajaran matematika di kelas pada materi pecahan masih belum optimal, hal ini karena, (1) pembelajaran yang dilakukan masih 
menggunakan metode ceramah, (2) siswa sering diberi contoh soal matematika dan diharuskan mengerjakan latihan berdasarkan contoh, (3) kurangnya media dan alat peraga, dan (4) sebagian besar materi yang disampaikan guru bersifat abstrak. Oleh karena itu, perlu adanya tindakan dalam meningkatkan kemampuan pemecahan masalah matematika siswa kelas IV SD 3 Tenggeles.

Cara guru mengajar yang terlalu menekankan pada penumpukan sejumlah informasi/konsep pada siswa dapat saja kurang bermanfaat bahkan tidak bermanfaat sama sekali, jika hal tersebut dikomunikasikan secara satu arah saja. Pada kenyataannya siswa lebih menghafal konsep yang diberikan guru dan kurang mampu menggunakan konsep tersebut dalam memecahkan masalah yang berhubungan dengan konsep tersebut. Guru dalam menyampaikan materi matematika tidak berorientasi pada kenyataan dan tidak terkait masalah kehidupan siswa, sehingga materi yang diajarkan belum tertanam dalam pemahaman siswa.

Hasil wawancara dengan guru kelas IV SD 3 Tenggeles menyatakan bahwa, masih terdapat siswa yang kurang mampu melatih keterampilan pemecahan masalah yang dimiliki. Berdasarkan keterangan dari guru, siswa mampu menyelesaikan soal matematika dengan cara dibimbing. Siswa mampu menyelesaikan soal-soal yang penyelesaiaanya membutuhkan hafalan rumus matematika. Mereka belum mampu mengasah pengetahuan dan keterampilannya untuk menyelesaikan soal matematika dalam bentuk soal cerita.

Hasil pengamatan di kelas IV SD 3 Tenggeles menunjukkan bahwa, kegiatan pembelajaran yang dilakukan belum menggunakan hal-hal yang berbasis masalah dan siswa tidak menyelesaikan suatu masalah dengan caranya sendiri melainkan meniru contoh yang diberikan guru. Pernyataan tersebut diperkuat dengan hasil wawancara siswa bahwa proses kegiatan pembelajaran matematika dilakukan dengan cara menyampaikan materi, pemberian contoh soal, dan mengerjakan soal-soal latihan. Hasil nilai ulangan siswa kelas IV SD 3 Tenggeles dalam menyelesaikan soal cerita menunjukkan bahwa masih terdapat siswa yang belum mencapai KKM. Nilai KKM di SD 3 Tenggeles untuk mata pelajaran matematika yaitu 60. Siswa yang sudah mencapai KKM sebanyak 9 siswa dan siswa yang belum mencapai KKM sebanyak 14 siswa. Hasil tersebut menunjukkan bahwa siswa kurang mampu memecahkan masalah matematika. Untuk itu, guru harus bijaksana dalam menemukan model yang dapat mengembangkan kemampuan memecahkan masalah dengan diberikan masalah-masalah yang menuntut siswa untuk berpikir secara kreatif.

Model pembelajaran berbasis masalah (disingkat PBM) memungkinkan dikembangkannya keterampilan berpikir siswa (penalaran, komunikasi, dan koneksi) dalam pemecahan masalah matematika. Menurut Tan (dalam Rusman, 2012:229), pembelajaran berbasis masalah merupakan inovasi dalam pembelajaran karena dalam PBM kemampuan berpikir siswa betul-betul dioptimalisasikan melalui proses kerja kelompok atau tim yang sistematis, sehingga siswa dapat memberdayakan, mengasah, menguji, dan mengembangkan kemampuan berpikirnya secara berkesinambungan.

Bruner (dalam Trianto, 2011:7) menjelaskan bahwa berusaha sendiri untuk mencari pemecahan masalah serta pengetahuan yang menyertainya, menghasilkan pengetahuan yang benar-benar bermakna. Dengan berusaha untuk mencari pemecahan masalah secara mandiri akan memberikan suatu pengalaman konkret pada siswa, sehingga ia dapat memecahkan masalah-masalah yang serupa karena pengalaman memberikan makna bagi dirinya.

Berdasarkan deskripsi tersebut, maka solusi untuk mengajarkan materi pecahan peneliti menggunakan model pembelajaran berbasis masalah karena pada pembelajaran berbasis masalah menyajikan masalah untuk diselesaikan dan siswa akan terbiasa untuk 
menyelesaikan masalah matematika. Oleh karena itu, peneliti mengambil judul penelitian "Peningkatan Kemampuan Pemecahan Masalah Matematika Siswa Kelas IV SD 3 Tenggeles Melalui Model Pembelajaran Berbasis Masalah Materi Pecahan".

Rumusan masalah penelitian ini, yaitu (1) apakah penerapan model pembelajaran berbasis masalah pada materi pecahan dapat meningkatkan kemampuan pemecahan masalah matematika siswa kelas IV SD 3 Tenggeles tahun ajaran 2013/2014?, (2) bagaimanakah aktivitas belajar siswa dalam memecahkan masalah dengan menerapkan model pembelajaran berbasis masalah materi pecahan pada siswa kelas IV SD 3 Tenggeles tahun ajaran 2013/2014?, dan (3) bagaimanakah keterampilan guru dalam pengelolaan pembelajaran matematika materi pecahan dengan menerapkan model pembelajaran berbasis masalah pada materi pecahan di kelas IV SD 3 Tenggeles tahun ajaran 2013/2014?

Tujuan penelitian ini, yaitu (1) mendeskripsikan peningkatan kemampuan pemecahan masalah matematika siswa kelas IV SD 3 Tenggeles materi pecahan melalui model pembelajaran berbasis masalah, (2) mendeskripsikan aktivitas belajar siswa dalam memecahkan masalah dengan menerapkan model pembelajaran berbasis masalah, dan (3) mendeskripsikan keterampilan guru dalam pengelolaan pembelajaran matematika materi pecahan dengan menerapkan model pembelajaran berbasis masalah.

\section{MASALAH MATEMATIKA DAN KEMAMPUAN PEMECAHAN MASALAH MATEMATIKA}

Winarni dan Sri Harmini (2012:117-118) menjelaskan bahwa masalah matematika, yang terdiri atas (1) masalah translasi, yaitu masalah dalam kehidupan sehari-hari yang dituangkan dalam bentuk verbal berkaitan dengan matematika, (2) masalah proses, yaitu masalah yang pengerjaannya diarahkan untuk menyususun langkah-langkah agar dirumuskan pola dan strategi khusus pemecahan masalah, (3) masalah teka-teki (menebak), yaitu masalah yang mengarah pada kegiatan matematika rekreasi dan membangkitkan kesenangan, sehingga tercipta penanaman sikap positif (afektif) terhadap matematika, (4) masalah aplikasi merupakan masalah yang kesempatan kepada siswa untuk menyelesaikan masalah dengan menggunakan berbagai keterampilan dan prosedur matematika.

Suherman (2003:89), mendefinisikan pemecahan masalah merupakan bagian dari kurikulum matematika yang sangat penting karena dalam proses pembelajaran maupun penyelesaian, siswa dimungkinkan memperoleh pengalaman menggunakan pengetahuan serta keterampilan yang sudah dimiliki untuk diterapkan pada pemecahan masalah yang bersifat tidak rutin. Polya (dalam Winarni dan Sri Harmini, 2012:124) berpendapat bahwa untuk memecahkan masalah dapat dilakukan dengan mengikuti empat langkah yang terdiri atas, (1) pemecahan terhadap masalah, maksudnya mengerti masalah dan melihat apa yang dikehendaki; (2) perencanaan pemecahan masalah; (3) melaksanakan perencanaan pemecahan masalah; dan (4) melihat kembali kelengkapan pemecahan masalah.

Ratumaman (dalam Trianto, 2011:92) menjelaskan bahwa pengajaran berdasarkan masalah merupakan pendekatan yang efektif untuk pengajaran proses berpikir tingkat tinggi. Pembelajaran ini membantu siswa untuk memproses informasi yang sudah jadi dalam benaknya dan menyusun pengetahuan mereka sendiri tentang dunia sosial dan sekitarnya. Pada model pembelajaran berbasis masalah, kelompokkelompok kecil siswa bekerja sama memecahkan suatu masalah yang telah disepakati oleh siswa dan guru. Menurut Ibrahim dan Nur (dalam Rusman, 2012:243) sintaks pengajaran berdasarkan masalah terdiri atas lima langkah, yaitu (1) memberikan orientasi tentang permasalahannya kepada siswa, (2) mengorganisasikan siswa untuk meneliti, (3) 
membantu investigasi individual dan kelompok, (4) mengembangkan dan mempresentasikan artefax dan exhibit, dan (5) menganalisis dan mengevaluasi proses pemecahan masalah.

Matematika, menurut Ruseffendi (dalam Heruman, 2012:1) yaitu bahasa simbol; ilmu deduktif yang tidak menerima pembuktian secara induktif; ilmu tentang pola keteraturan, dan struktur yang terorganisasi, mulai dari unsur yang tidak didefinisikan, ke aksioma atau postulat, dan akhirnya ke dalil. Heruman (2012:2) memaparkan bahwa tujuan akhir pembelajaran matematika SD yaitu membentuk siswa untuk terampil dalam menggunakan berbagai konsep matematika. Ruang lingkup pembelajaran matematika di Sekolah Dasar mencakup beberapa standar kompetensi. Standar kompetensi matematika dikelompokkan ke dalam beberapa kemampuan. Menurut BSNP (2006:148) ruang lingkup mata pelajaran matematika pada satuan pendidikan SD/MI, yaitu (1) bilangan, (2) geometri dan pengukuran, serta (3) pengolahan data.

Heruman (2007:43) mendefinisikan pecahan sebagai bagian dari sesuatu yang utuh. Pecahan dapat dinyatakan dalam bentuk $\frac{\mathrm{a}}{\mathrm{b}}$, a disebut pembilang, sedangkan $\mathrm{b}$ disebut penyebut. Pusat Pengembangan Kurikulum dan Sarana Pendidikan Badan Penelitian dan Pengembangan (dalam Heruman, 2007:43) menyatakan bahwa pecahan merupakan salah satu topik yang sulit untuk diajarkan. Kesulitan itu terlihat dari kurang bermaknannya kegiatan pembelajaran yang dilakukan guru, dan sulitnya pengadaan media pembelajaran. Operasi hitung pecahan yang akan digunakan pada penelitian ini yaitu operasi hitung penjumlahan dan pengurangan pecahan, khususnya pada materi menyelesaikan masalah yang berkaitan dengan penjumlahan pecahan dan pengurangan pecahan. Materi tersebut terletak pada standar kompetensi menggunakan pecahan dalam pemecahan masalah, serta terletak pada kompetensi dasar 6.5 menyelesaikan masalah yang berkaitan dengan pecahan.

\section{METODE PENELITIAN}

Penelitian ini merupakan penelitian tindakan kelas. Arikunto (2010:130) menyatakan penelitian tindakan kelas merupakan suatu pencermatan terhadap kegiatan yang sengaja dimunculkan, dan terjadi dalam sebuah kelas. Penelitian ini menggunakan desain Penelitian Tindakan Kelas (PTK) model Kemmis \& McTaggart. Pada model yang dikemukakan oleh Kemmis \& McTaggart, terdapat beberapa tahapan yang saling terkait antara tahapan satu dengan tahapan berikutnya. Tahapan dalam model penelitian ini terdiri atas, (1) perencanaan tindakan, (2) perlakuan dan pengamatan tindakan, dan (3) refleksi terhadap tindakan.

Penelitian dilaksanakan di kelas IV SD 3 Tenggeles Kecamatan Mejobo Kabupaten Kudus. Siswa kelas IV berjumlah 23 orang yang terdiri atas 14 orang siswa laki-laki dan 9 orang siswa perempuan. Kemampuan yang dimiliki siswa berbeda-beda. Kemampuan yang dimiliki dapat dilihat dari hasil nilai ulangan yang berkaitan dengan penyelesaian soal cerita, dimana masih terdapat siswa yang belum mencapai KKM. Hasil nilai ulangan yang terkait dengan soal cerita menunjukkan bahwa 39,13\% dari seluruh siswa sudah mencapai KKM dan 60,87\% dari seluruh siswa belum mencapai KKM. Hasil pembelajaran matematika tersebut dipengaruhi oleh kreatifitas guru dalam melakukan pembelajaran untuk menyelesaikan soal cerita.

Variabel bebas pada penelitian ini yaitu model pembelajaran berbasis masalah, sedangkan variabel terikatnya yaitu kemampuan pemecahan masalah matematika materi pecahan pada siswa kelas IV SD 3 Tenggeles, Mejobo, Kudus tahun ajaran 2013/2014. Teknik pengumpulan data menggunakan teknik (1) wawancara, (2) observasi, (3) tes, dan (4) dokumentasi. Instrumen pada penelitian berupa, (1) pedoman wawancara, (2) 
pedoman observasi, dan (3) tes. Dalam pelaksanaan penelitian tindakan kelas ini, peneliti menggunakan teknik analisis data secara kuantitatif dan kualitatif.

Data kuantitatif berupa peningkatan kemampuan pemecahan masalah yang mengukur tingkat kognitif siswa. Data kuantitatif dianalisis menggunakan teknik analisis deskriptif dengan menentukan nilai tes kemampuan pemecahan masalah, kriteria ketuntasan siswa dalam mengerjakan soal tes kemampuan pemecahan masalah, menghitung persentase ketuntasan hasil belajar klasikal dalam mengerjakan soal tes kemampuan pemecahan masalah, dan menghitung nilai rata-rata kelas. Data kualitatif diperlukan untuk mendukung data kuantitatif. Data kualitatif berupa informasi berbentuk kalimat. Data kualitatif pada penelitian ini diperoleh dari data hasil observasi aktivitas belajar siswa dan keterampilan guru dalam pembelajaran matematika melalui model pembelajaran berbasis masalah.

Keberhasilan kinerja dengan menerapkan model pembelajaran berbasis masalah dapat meningkatkan kemampuan pemecahan masalah matematika siswa kelas IV SD 3 Tenggeles tahun ajaran 2013/2014 dengan indikator keberhasilan yang terdiri atas (1) kemampuan siswa kelas IV semester 2 SD 3 Tenggeles dalam memecahkan masalah matematika materi pecahan mencapai nilai rata-rata kelas minimal $\geq 60$ dengan persentase ketuntasan belajar klasikal minimal mencapai 75\%, (2) aktivitas belajar siswa kelas IV semester 2 SD 3 Tenggeles dalam memecahkan masalah matematika melalui model pembelajaran berbasis masalah memiliki kriteria minimal baik dengan skor ratarata $>2,5$, dan (3) keterampilan guru dalam pengelolaan pembelajaran matematika dengan menggunakan model pembelajaran berbasis masalah memiliki kriteria minimal baik dengan skor rata-rata $>2,5$.

\section{HASIL PENELITIAN DAN PEMBAHASAN}

Penelitian siklus I dilakukan selama 4 jam pelajaran (4 x 35 menit) yang terbagi menjadi dua kali pertemuan. Siklus I pertemuan pertama dilaksanakan pada 17 Mei 2014 dan pertemuan kedua dilaksanakan pada 26 Mei 2014. Penelitian tindakan kelas siklus I dilaksanakan dengan menerapkan model pembelajaran berbasis masalah materi menyelesaikan masalah yang berkaitan dengan penjumlahan pecahan.

Penelitian siklus II dilakukan selama 4 jam pelajaran $(4$ x 35 menit $)$ yang terbagi menjadi dua kali pertemuan. Siklus II pertemuan pertama dilaksanakan pada 28 Mei 2014 dan pertemuan kedua dilaksanakan pada 31 Mei 2014. Penelitian tindakan kelas siklus II dilaksanakan dengan menerapkan model pembelajaran berbasis masalah materi menyelesaikan masalah yang berkaitan dengan pengurangan pecahan.

Pengukuran kemampuan pemecahan masalah pada penelitian ini, dilakukan dengan membandingkan nilai pra siklus dengan nilai tes kemampuan pemecahan masalah pada siklus I dan siklus II. Tes kemampuan pemecahan masalah dilakukan setiap akhir siklus pembelajaran dengan menerapkan model pembelajaran berbasis masalah materi menyelesaikan masalah yang berkaitan dengan pecahan.

Hasil tes kemampuan pemecahan masalah siswa kelas IV pada tahap pra siklus memperoleh nilai rata-rata 54,35 dengan persentase ketuntasan $39,13 \%$. Siswa yang nilainya memenuhi KKM sebanyak 9 siswa, sedangkan yang belum mencapai KKM sebanyak 14 siswa. Pelaksanaan penelitian siklus I, menunjukkan bahwa hasil nilai tes kemampuan pemecahan masalah memperoleh nilai rata-rata 63,17 dengan persentase ketuntasan $65,22 \%$. Tes kemampuan pemecahan masalah pada siklus I berupa tes tertulis dalam bentuk 5 soal uraian materi menyelesaikan masalah yang berkaitan dengan penjumlahan pecahan. Pembelajaran siklus I peneliti menemukan ada 15 siswa yang nilainya sudah mencapai KKM, sedangkan jumlah siswa yang nilainya belum mencapai 
KKM sebanyak 8 siswa. Pada siklus I, peneliti menganalisis kemampuan pemecahan masalah siswa dilihat dari perolehan skor tes siklus I. Peneliti menemukan ada 5 siswa yang memiliki kemampuan pemecahan masalah dengan kategori buruk, 3 siswa dengan kategori kurang, 6 siswa dengan kategori cukup, 8 siswa dengan kategori baik, dan 1 siswa dengan kategori sangat baik.

Pelaksanaan penelitian siklus II, menunjukkan bahwa hasil nilai tes kemampuan pemecahan masalah memperoleh nilai rata-rata 75,13 dengan persentase ketuntasan $86,96 \%$. Tes kemampuan pemecahan masalah pada siklus II berupa tes tertulis dalam bentuk 5 soal uraian materi menyelesaikan masalah yang berkaitan dengan pengurangan pecahan. Pembelajaran siklus II peneliti menemukan ada 20 siswa yang nilainya sudah mencapai KKM, sedangkan jumlah siswa yang nilainya belum mencapai KKM sebanyak 3 siswa. Pada siklus II, peneliti menganalisis kemampuan pemecahan masalah siswa dilihat dari perolehan skor tes siklus II. Peneliti menemukan ada 3 siswa yang memiliki kemampuan pemecahan masalah dengan kategori kurang, 1 siswa dengan kategori cukup, 9 siswa dengan kategori baik, dan 10 siswa dengan kategori sangat baik.

Hasil analisis tes kemampuan pemecahan masalah, menunjukkan bahwa masih ada 3 siswa yang nilainya belum memenuhi KKM dari pra siklus sampai siklus II. Hal ini dikarenakan mereka belum terbiasa menyelesaikan masalah sesuai dengan langkahlangkah penyelesaian masalah secara lengkap. Mereka masih terbiasa menjawab soal dengan menulis jawabannya saja tanpa disertai dengan langkah-langkah penyelesaiannya. Selain itu, mereka memiliki minat belajar yang rendah, kurang aktif dalam pembelajaran, dan kemampuan yang dimiliki rendah. Adapun Sudjana (2010:39) menjelaskan bahwa faktor-faktor yang mempengaruhi hasil belajar, yaitu kemampuan yang dimiliki siswa, motivasi belajar, minat dan perhatian, sikap dan kebiasaan belajar, ketekunan, sosial ekonomi, faktor fisik, faktor psikis, dan faktor lingkungan.

Penilaian aktivitas belajar siswa dalam pemecahan masalah dilakukan dengan pedoman lembar observasi aktivitas belajar siswa dalam pemecahan masalah melalui model pembelajaran berbasis masalah. Hasil penilaian lembar observasi aktivitas belajar siswa dalam pemecahan masalah matematika dengan menerapkan model pembelajaran berbasis masalah pada siklus I pertemuan I memperoleh skor rata-rata 2,45 dan pada pertemuan II memperoleh skor rata-rata 2,67, sehingga hasil skor rata-rata pengamatan keterampilan aktivitas siswa pada siklus I yaitu 2,56 dengan kualifikasi baik. Hasil pengamatan aktivitas siswa dalam pemecahan masalah pada siklus I menunjukkan bahwa terdapat 13 siswa yang mendapatkan skor rata-rata dengan kategori cukup baik dan 10 siswa mendapatkan skor rata-rata dengan kategori baik.

Aspek pemecahan masalah pada siklus I memperoleh skor rata-rata dengan rincian (1) aspek memahami masalah memperoleh skor rata-rata 2,46 dengan kategori cukup baik, (2) aspek merencanakan pemecahan masalah memperoleh skor rata-rata 3 dengan kategori baik (3) aspek melaksanakan perencanaan pemecahan masalah memperoleh skor rata-rata 2,66 dengan kategori baik, dan (4) aspek melihat kembali kelengkapan pemecahan masalah memperoleh skor rata-rata 2,33 dengan kategori cukup baik.

Model pembelajaran berbasis masalah merupakan model pembelajaran yang mengajarkan siswa untuk mengasah, menguji, dan mengembangkan kemampuan berpikirnya secara berkesinambungan, sehingga dapat menyelesaikan suatu masalah. Dalam pembelajaran berbasis masalah siswa akan memecahkan masalah dan mereka akan mendapatkan pengalaman konkret dari langkah-langkah penyelesaian masalah yang dilakukannya. Bruner (dalam Trianto, 2011:7) menjelaskan bahwa berusaha sendiri untuk mencari pemecahan masalah serta pengetahuan yang menyertainya, menghasilkan pengetahuan yang benar-benar bermakna. 
Pembelajaran siklus II dilakukan dengan memperbaiki pembelajaran sebelumnya. Perbaikan yang dilakukan peneliti meningkatkan aktivitas siswa dalam pemecahan masalah melalui model pembelajaran berbasis masalah. Hasil pengamatan terhadap aktivitas siswa dalam pemecahan msalah pada siklus II pertemuan I memperoleh skor rata-rata 2,91 dan pada pertemuan II memperoleh skor rata-rata 3,13, sehingga hasil skor rata-rata pengamatan aktivitas siswa pada siklus II yaitu 3,02 dengan kualifikasi baik. Berdasarkan hasil penelitian yang telah dilakukan, aktivitas belajar siswa dalam pemecahan masalah meningkat dari 2,56 pada siklus I menjadi 3,02 pada siklus II. Peningkatan aktivitas belajar siswa dalam pemecahan masalah sebesar 0,46. Hasil pengamatan aktivitas siswa dalam pemecahan masalah melalui model pembelajaran berbasis masalah pada siklus II menunjukkan bahwa 21 siswa mendapatkan skor rata-rata dengan kategori baik dan 2 siswa mendapatkan skor rata-rata dengan kategori sangat baik.

Aspek kemampuan pemecahan masalah pada siklus II mengalami peningkatan. Perolehan skor rata-rata kemampuan pemecahan masalah pada silus II, yaitu (1) aspek memahami masalah memperoleh skor rata-rata 2,94 dengan kategori baik, (2) aspek merencanakan pemecahan masalah memperoleh skor rata-rata 3,39 dengan kategori sangat baik (3) aspek melaksanakan perencanaan pemecahan masalah memperoleh skor rata-rata 3,26 dengan kategori sangat baik, dan (4) aspek melihat kembali kelengkapan pemecahan masalah memperoleh skor rata-rata 2,81 dengan kategori baik.

Penilaian keterampilan guru dilakukan dengan menggunakan lembar observasi keterampilan guru dalam pengelolaan pembelajaran matematika. Selama melaksanakan penelitian pada siklus I dan siklus II, peneliti dinilai keterampilannya selama mengajar. Hasil penilaian lembar observasi keterampilan guru (peneliti) dalam pembelajaran matematika dengan menerapkan model pembelajaran berbasis masalah pada siklus I pertemuan I memperoleh skor rata-rata 2,74 dan pada pertemuan II memperoleh skor rata-rata 2,89, sehingga hasil skor rata-rata pengamatan keterampilan guru (peneliti) dalam pembelajaran pada siklus I yaitu 2,82 dengan kualifikasi baik. Hasil pengamatan terhadap keterampilan mengajar guru (peneliti) pada siklus II pertemuan I memperoleh skor rata-rata 3,05 dan pada pertemuan II memperoleh skor rata-rata 3,16, sehingga hasil skor rata-rata pengamatan keterampilan guru (peneliti) dalam pembelajaran pada siklus II yaitu 3,11 dengan kualifikasi baik. Berdasarkan hasil penelitian yang telah dilakukan, keterampilan guru (peneliti) dalam pengelolaan pembelajaran matematika meningkat dari 2,82 pada siklus I menjadi 3,11 pada siklus II. Peningkatan keterampilan peneliti dalam mengajar sebesar 0,29.

Penelitian yang telah dilakukan peneliti, sejalan dengan penelitian yang dilakukan oleh salah satu peneliti sebelumnya, yaitu Prasetyoningsih (2013) yang melakukan penelitian penerapan model pembelajaran berdasarkan masalah untuk meningkatkan kemampuan pemecahan masalah siswa pada mata pelajaran IPA SD. Penelitian yang dilakukan oleh Prasetyoningsih memberikan hasil bahwa terjadi peningkatan kemampuan pemecahan masalah, persentase ketuntasan kemampuan pemecahan masalah, aktivitas siswa, dan aktivitas guru. Jadi, peneliti menyimpulkan bahwa penerapan model pembelajaran berbasis masalah dapat meningkatkan kemampuan pemecahan masalah, aktivitas siswa dalam pemecahan masalah, dan keterampilan guru dalam pengelolaan pembelajaran.

\section{SIMPULAN}

Berdasarkan hasil penelitian tindakan kelas yang dilakukan dapat disimpulkan bahwa penerapan model pembelajaran berbasis masalah pada materi pecahan dapat 
meningkatkan kemampuan pemecahan masalah matematika siswa kelas IV SD 3 Tenggeles. Peningkatan tersebut dapat dilihat dari hasil penelitian sebagai berikut.

1. Kemampuan pemecahan masalah siswa mengalami peningkatan, yaitu pada tahap pra siklus nilai rata-rata 54,35 dengan persentase ketuntasan 39,13\%, meningkat menjadi 63,17 dengan persentase ketuntasan $65,22 \%$ pada siklus I, dan 75,13 dengan persentase ketuntasan $86,96 \%$ pada siklus II.

2. Aktivitas belajar siswa kelas IV SD 3 Tenggeles dalam pemecahan masalah melalui model pembelajaran berbasis masalah mengalami peningkatan, yaitu pada siklus I aktivitas belajar siswa dalam pemecahan masalah memperoleh skor rata-rata 2,56 dengan kualifikasi baik mengalami peningkatan pada siklus II yang memperoleh skor rata-rata 3,02 dengan kualifikasi baik.

3. Keterampilan guru (peneliti) dalam pengelolaan pembelajaran matematika dengan menerapkan model pembelajaran berbasis masalah mengalami peningkatan, yaitu pada siklus I keterampilan mengajar peneliti memperoleh skor rata-rata 2,82 dengan kualifikasi baik mengalami peningkatan pada siklus II yang memperoleh skor ratarata 3,11 dengan kualifikasi baik.

\section{SARAN}

Berdasarkan penelitian yang sudah dilakukan, maka peneliti mengajukan saran sebagai berikut.

1. Siswa hendaknya mendengarkan penjelasan dari guru dan melatih mengerjakan soal dengan langkah-langkah pemecahan masalah.

2. Siswa hendaknya membiasakan diri untuk memeriksa kembali hasil pemecahan masalah yang telah dilakukan setelah mengerjakan soal pemecahan masalah.

3. Guru hendaknya mengajarkan langkah-langkah pemecahan masalah secara runtut dan lengkap, yaitu memahami masalah, merencanakan pemecahan masalah, melaksanakan perencanaan pemecahan masalah, dan melihat kembali kelengkapan pemecahan masalah.

4. Guru diharapkan dapat menerapkan model pembelajaran berbasis masalah sebagai alternatif pemilihan model pembelajaran. Hal ini dikarenakan dengan menerapkan model pembelajaran berbasis masalah dapat meningkatkan kemampuan pemecahan masalah dan aktivitas siswa dalam memecahkan masalah.

5. Peneliti selanjutnya dapat mengembangkan penelitian dengan menggunakan model pembelajaran berbasis masalah dan mengajarkan langkah-langkah pemecahan masalah secara runtut.

\section{DAFTAR PUSTAKA}

Arikunto, Suharsimi. 2010. Prosedur Penelitian: Suatu Pendekatan Praktik. Jakarta:Rineka Cipta

BSNP. 2006. Standar Isi Untuk Satuan Pendidikan Dasar dan Menengah: Standar Kompetensi dan Kompetensi Dasar SD/MI. Jakarta: BSNP

Heruman. 2012. Model Pembelajaran Matematika di Sekolah Dasar. Bandung: Remaja Rosdakarya

Prasetyoningsih, Desi Swi. 2013. Penerapan Model Pembelajaran Berdasarkan Masalah untuk Meningkatkan Kemampuan Pemecahan Masalah Siswa Pada Mata Pelajaran IPA SD (Volume 01 Nomor 02). [online]. JPGSD, 01(02). Hal. 1-14. Tersedia pada http://ejournal.unesa.ac.id/index.php/jurnal-penelitian. Diakses pada tanggal 10 Desember 2013. 
Rusman. 2012. Model-model Pembelajaran: Mengembangkan Profesionalisme Guru. Jakarta: Rajawali Pers.

Sudjana, Nana. 2010. Dasar-dasar Proses Belajar Mengajar. Bandung: Sinar Baru Algesindo.

Suherman, Erman, dkk. 2003. Strategi Pembelajaran Matematika Kontemporer. Bandung: Universitas Pendidikan Indonesia

Trianto. 2011. Mendesain Model Pembelajaran Inovatif-Progresif. Jakarata: Kencana.

Winarni, Endang Setyo dan Sri Harmini. 2012. Matematika Untuk PGSD. Bandung: PT. Remaja Rosdakarya. 